\title{
A Strategy for Developing a Market for Nonperforming Loans in Italy
}




\title{
A Strategy for Developing a Market for Nonperforming Loans in Italy
}

\author{
Nadège Jassaud and Kenneth Kang
}




\title{
IMF Working Paper
}

European Department and Strategy Policy and Review Department

\section{A Strategy for Developing a Market for Nonperforming Loans in Italy Prepared by Nadège Jassaud and Kenneth Kang ${ }^{1}$}

Authorized for distribution by Vikram Haksar and Petya Koeva Brooks

February 2015

\section{This Working Paper should not be reported as representing the views of the IMF.}

The views expressed in this Working Paper are those of the author(s) and do not necessarily represent those of the IMF or IMF policy. Working Papers describe research in progress by the author(s) and are published to elicit comments and to further debate.

\begin{abstract}
Addressing the buildup of nonperforming loans (NPLs) in Italy since the global financial crisis will remain a challenge for some time and be important for supporting a sustained, robust economic recovery. The buildup reflects both the prolonged recession as well as structural factors that have held back NPL write-offs by banks. The paper discusses the impediments to NPL resolution in Italy and a strategy for fostering a market for restructuring distressed assets that could support corporate and financial restructuring.

JEL Classification Numbers: E440, K22, G33, G38

Keywords: NPLs, NPL disposal, distressed assets, problem loans, bad debt, write-offs, corporate restructuring, debt restructuring, bad bank, AMCs, Asset Quality Review, Balance Sheet Assesment, Resolution.

Author's E-Mail Address: njassaud@,imf.org; kkang@,imf.org

\footnotetext{
${ }^{1}$ This paper, which expands on the findings of the IMF Article IV and Selected Issues Paper (2013), has benefited from comments and inputs received from colleagues at the Italian Ministry of Economy and Finance, Bank of Italy, academia (Jan-Pieter Krahnen and Michael Schneider, University of Frankfurt) and market participants (in particular, Daniela Andreatta, Patrizio Messina, Ettore Consalvi, Francesco Faldi, Jacopo Lambri, and Paola Sabione). David Velazquez and Jesse Siminitz provided valuable research support, and Sasha Pitrof and Katherine Cincotta provided editorial assistance. Any remaining errors in the paper are ours. The views expressed are our own and are not necessarily the official views of the IMF.
} 
Abbreviations and Acronyms

I. Introduction ..$\underline{5}$

II. Current Situation with Nonperforming Loans in Italy ..... ..$\underline{6}$

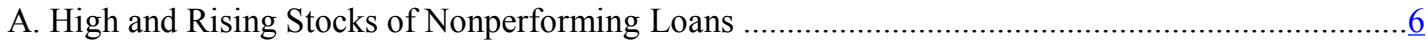

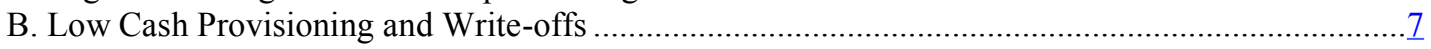

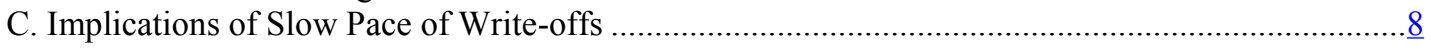

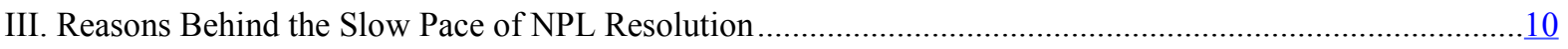

A. Supply Factors: Limited Incentives for Banks to Sell and Write Off..............................................11

B. Demand Factors: High Cost and Limited Options for Restructuring ............................................. 14

IV. A Strategy for Developing a Market for Nonperforming Loans in Italy ...................................................15

A. Benefits of a Market for Nonperforming Loans …………...................................................

B. Current State of the Distressed Debt Market ..............................................................................

C. Strategy for Fostering a Market for Nonperforming Loans ............................................................19

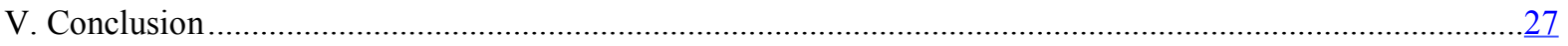

Figures

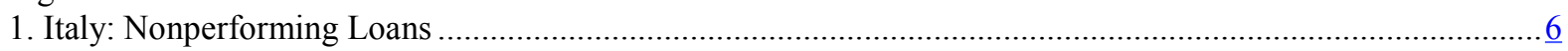

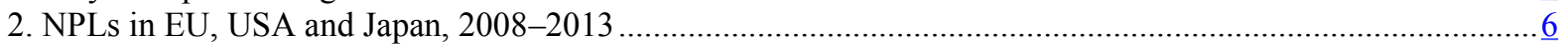

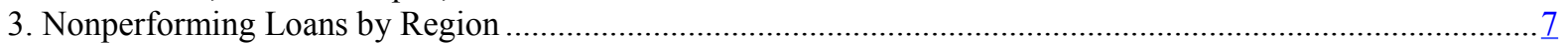

4. Corporate Leverage in Italy and Euro Area, 2014Q1 …....................................................................

5. Nonperforming Loans and Coverage Ratio, June 2014 ….........................................................................

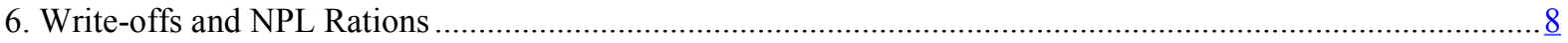

7. Bad Debt Ratio for Different Rates of Write-offs ....................................................................................

8. NPL Ratio Versus 5Y Credit Default Swap Spreads, June 2014 ..............................................................10

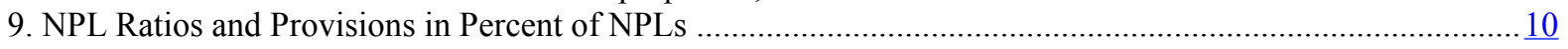

10. Nonperforming Loans Net of Provisions to Capital, June 2014 ……......................................................11

11. Nonperforming Exposures Before and After the ECB AQR in Italian Banks, December 2013 ...................12

12. Nonperforming Loans in Japan ................................................................................................ 16

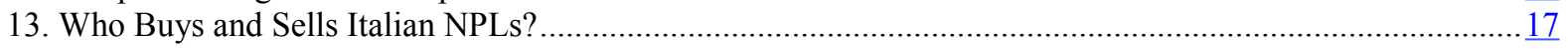

14. Distressed Debt Markets in Europe ……………….......................................................................

15. Stocks of Nonperforming Loans in the Corporate Sector, March 2014 ....................................................21

16. Bank-led Voluntary Restructuring Process for Corporate Loans .................................................................. 24

Boxes

1. Calculating the Cost of Capital for Holding Nonperforming Loans ............................................................. 9

2. The European Central Bank's Balance Sheet Assessment and Results for Italy ............................................12

3. How Does the Accounting Approach to Accured Interest Disincentivize Write-offs? ...................................14

4. Japan's Experience with Distressed Loan Markets ……………………....................................................... 16

5. UniCredit and Intesa Partnership Initiative with Kohlberg Kravis Roberts and Alvarez \& Marsal .................. 18

6. International Practices for the Write-off of Nonperforming Loans ............................................................... 20

7. The Swedish Approach of Nonperforming Loan Resolution ……...........................................................21

8. The Icelandic Crisis and the Corporate Debt Restructuring ……................................................................24

9. Korea's Experience with Corporate Restructuring ……....................................................................... 26

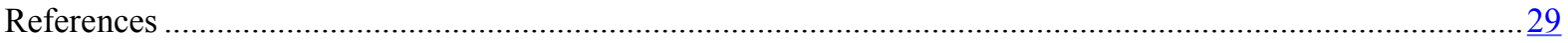


AbBreviations AND ACRONYMS

$\begin{array}{ll}\text { A\&M } & \text { Alvarez \& Marsal } \\ \text { ABS } & \text { Asset Backed Securities } \\ \text { AMC } & \text { Asset Management Company } \\ \text { AQR } & \text { Asset Quality Review } \\ \text { BoI } & \text { Bank of Italy } \\ \text { BSA } & \text { Balance Sheet Assessment } \\ \text { CET1 } & \text { Common Equity Tier One } \\ \text { CRC } & \text { Corporate Restructuring Company } \\ \text { CRF } & \text { Corporate Restructuring Fund } \\ \text { CRV } & \text { Corporate Restructuring Vehicle } \\ \text { DFA } & \text { Deferred Tax Asset } \\ \text { FSA } & \text { Financial Service Authority } \\ \text { FSS } & \text { Financial Supervisory Service } \\ \text { HQS } & \text { High-Quality Securitization } \\ \text { ICR } & \text { Interest Coverage Ratio } \\ \text { IRBA } & \text { Internal Ratings-Based Advanced } \\ \text { IRBF } & \text { Internal Ratings-Based Foundation } \\ \text { IRR } & \text { Internal Rate of Return } \\ \text { ISP } & \text { Intesa San Paolo } \\ \text { KAMCO } & \text { Korea Asset Management Company } \\ \text { KKR } & \text { Kohlberg Kravis Roberts } \\ \text { NCA } & \text { Noncore asset } \\ \text { NPE } & \text { Nonperforming Exposure } \\ \text { NPL } & \text { Nonperforming Loan } \\ \text { RCC } & \text { Resolution and Collection Corporation } \\ \text { RWA } & \text { Risk Weighted Asset } \\ \text { SME } & \text { Small- and Medium-Sized Enterprise } \\ \text { SPV } & \text { Special Purpose Vehicle } \\ \text { SSM } & \text { Single Supervisory Mechanism } \\ \text { UCG } & \text { UniCredit Group } \\ \text { UL } & \text { Unexpected Loss } \\ & \end{array}$




\section{INTRODUCTION}

High and rising levels of nonperforming loans (NPLs) in Italy continue to weigh on banks' balance sheets. Since the onset of the global financial crisis, NPLs have more than tripled to 17 percent (June $2014^{2}$ ) of total loans, from just above 5 percent in 2007 . The rapid rise reflects in part the prolonged recession which has worsened the creditworthiness of borrowers, particularly small- and medium-sized enterprises (SMEs). At the same time, the inefficient and lengthy judicial process, combined with the limited incentives to write off loans, has held back the pace of NPL resolution. Without a significant pick-up in write-offs, NPLs will continue to remain high and a drag on bank profitability and market confidence.

The Italian authorities have taken a number of measures to promote NPL resolution. The Bank of Italy (BoI) special inspections and the ECB Asset Quality Review (AQR) have enhanced the transparency of problem loans and boosted provisioning. Recent tax reforms have also made it more favorable for banks to set aside loan loss provisions. As a result, banks have increased provisioning against bad loans and raised additional capital, along with announcing plans to offload some of their NPL portfolio.

To complement these efforts, further development of a market for restructuring NPLs in Italy would allow banks to more rapidly and efficiently address their distressed assets. ${ }^{3}$ As seen in other countries, involving outside investors in either directly purchasing NPLs or working with banks to restructure distressed borrowers can help Italian banks to reduce their NPL stock and over time, become a regular tool for managing bad loans. Interest in a distressed debt market is growing in Europe, with NPL transactions estimated to have reached $€ 64$ billion in 2013. ${ }^{4}$ The market in Italy has also picked up, with the announcement by two of the largest banks, UniCredit (UCG) and Intesa (ISP), to partner with outside investors in setting up special purpose vehicles (SPVs) to manage a portion of their NPLs.

This paper discusses a strategy to foster a distressed debt market that would contribute to addressing the NPL and debt overhang problem. Such a market would relieve the burden on banks for debt collection and collateral foreclosure, by boosting the recovery values of bad loans and leveraging outside financing and expertise. Facilitating debt restructuring and equity conversions could also inject significant capital into the corporate sector and help promote "good" deleveraging. Ultimately, such a market could generate a virtuous circle, where progress in cleaning banks' balance sheets and restructuring distressed

\footnotetext{
${ }^{2}$ BoI, consolidated data.

${ }^{3}$ In an address at the Italian Banking Association Annual Meeting in July 2014, Bank of Italy Governor Ignazio Visco also highlighted the benefits of developing a secondary market for NPLs.

${ }^{4}$ PricewaterhouseCoopers, 2014.
} 
borrowers strengthens confidence, improves bank profitability, and frees up resources to support new lending in a recovery. ${ }^{5}$

The paper is organized as follows: Section II describes the current situation with NPLs in Italy, while Section III outlines the factors behind the slow pace of NPL resolution. Building on international experience, Section IV describes the potential benefits of a market for NPLs for Italy and ways to foster its development; Section V concludes.

\section{CURRENT SituAtion WITH NONPERForming LoANS IN ITALY}

\section{A. High and Rising Stocks of Nonperforming Loans}

Nonperforming loans in Italy have tripled since 2007, reaching a historical peak. NPLs in Italy cover four categories: "bad debt" (loans in a state of insolvency), "substandard," "past due," and "restructured" loans (Figure 1). NPLs have grown at around 20 percent annually since 2008, topping €333 billion in June 2014 (24 percent of GDP or 16.8 percent of total loans). The worst NPL category_-sofferenze or "bad debt" - has increased the most and now accounts for more than half of total NPLs. Compared to the European average, the NPL ratio in Italy is more than four times greater ${ }^{6}$ and has increased at a much faster pace (Figure 2).
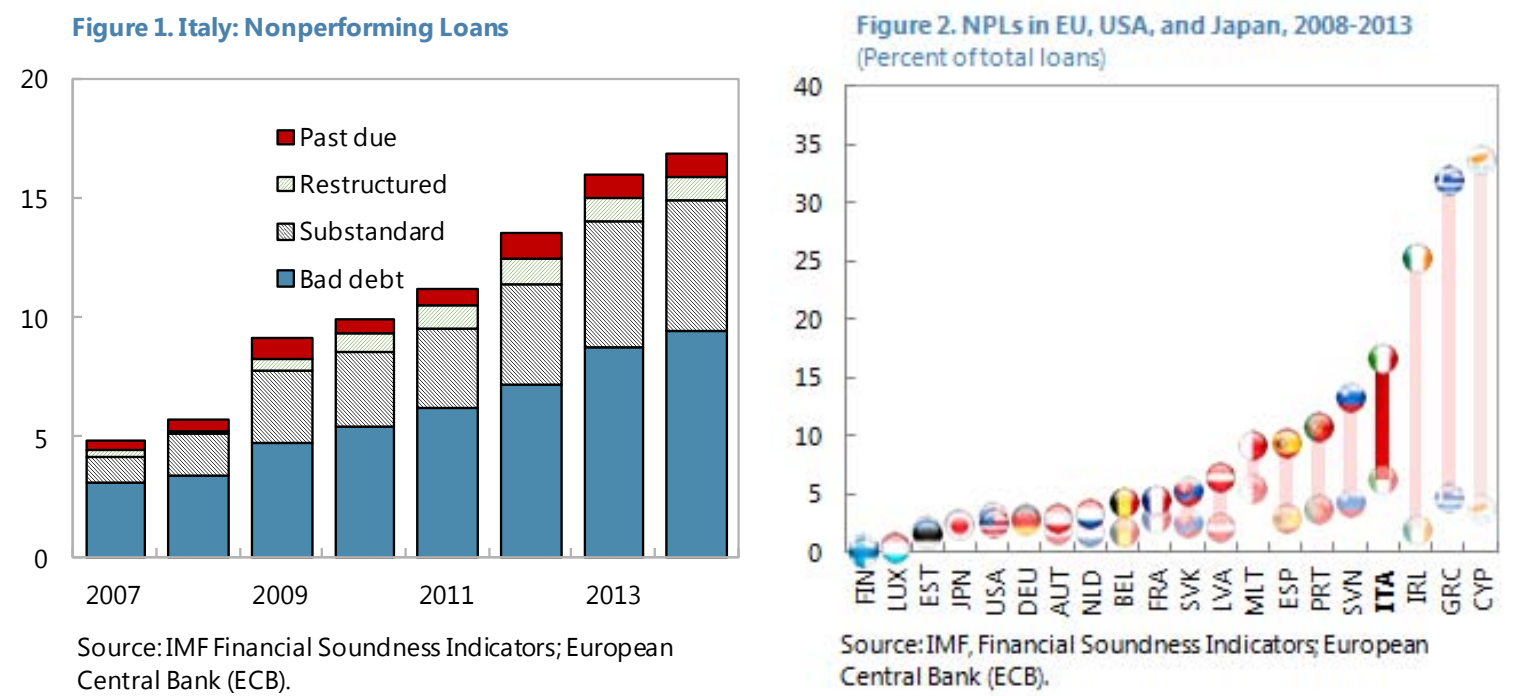

More than 80 percent of bank NPLs are in the corporate sector. ${ }^{7}$ Corporate NPL ratios have reached nearly 30 percent on average in 2014 and are significantly higher in the South (Figure 3). High corporate NPLs reflect both weak profitability in a severe recession as well the heavy indebtedness of many Italian firms, especially SMEs, which are among the highest

\footnotetext{
${ }^{5}$ Private Sector Deleveraging and Growth Following Busts," 2014, by Sally Chen, Minsuk Kim, Marijn Otte, Kevin Wiseman, Aleksandra Zdzienicka, IMF WP forthcoming.

${ }^{6}$ In some cases, comparisons may be undermined by differences in the NPL definitions adopted in the different IFRS jurisdictions. Since January 2015, BoI has aligned the Italian definition of NPLs to the nonperforming exposure (NPE) and forbearance notion provided by the EU regulation on supervisory reportings.

${ }^{7}$ BoI. As of March 2014, corporate loans amount to $€ 1,037$ billion (52 percent of total bank loans in Italy), of which corporate NPLs account for almost $€ 300$ billion (solo basis data).
} 
in the Euro Area (Figure 4). This picture is consistent with corporate survey data which shows nearly 30 percent of corporate debt owed by firms whose earnings (before interest and taxes) are insufficient to cover their interest payments. ${ }^{8}$

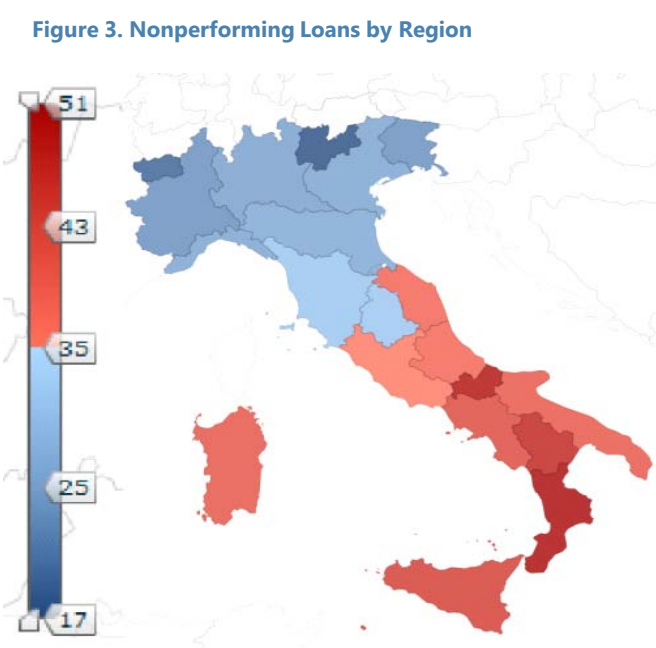

Source: IMF staff calculations.

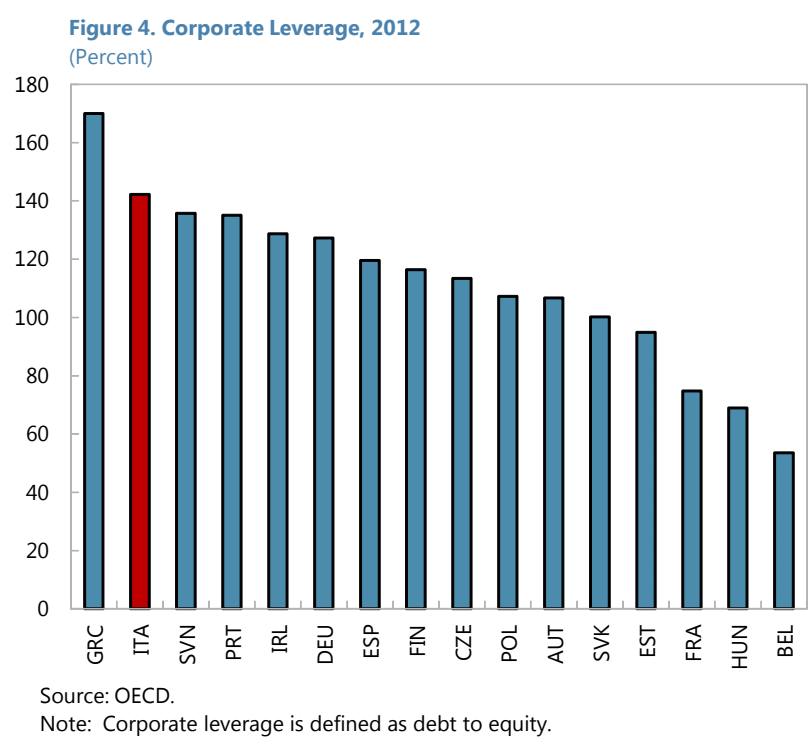

B. Low Cash Provisioning and Write-offs

\section{Provisioning coverage has not kept pace with the rise of NPLs and is uneven across} banks. The average provisioning coverage for Italian banks has declined from 48 percent in 2007 to a low of 37 percent in June 2012. As a result of the BoI's special loan inspections and in preparation for the European $\mathrm{AQR}$, provisioning coverage has subsequently increased to 42 percent in June 2014. The improvement, however, varies, with midsized $^{9}$ and smaller banks featuring lower coverage ratios (Figure 5). ${ }^{10}$

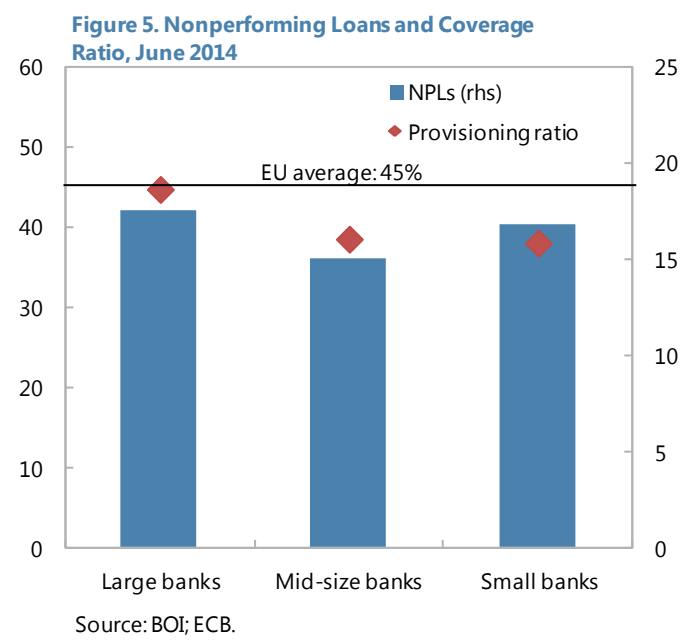

The pace of NPL write-offs has also slowed. The average time for writing off a bad loan has increased to over six years, ${ }^{11}$ from just under four years before the crisis. In 2013, on average less than 10 percent of bad debt, despite already being in a state of insolvency, was

\footnotetext{
${ }^{8}$ IMF Global Financial Stability Report, April 2014.

${ }^{9}$ In this paper, the large banks refer to the top 5 Italian banks in terms of total assets. Mid-sized banks refer to the 6 th to 15 th largest Italian banks. Small and minor banks refer to banks beyond the 16th largest bank.

${ }^{10}$ On average, smaller banks display higher capital ratios.

${ }^{11}$ BoI Financial Stability Review, April 2013 and IMF Detailed Assessment of Observance of Basel Core Principles for Effective Banking Supervision, December 2013, page 120 (stressing the age of the NPL portfolio in Italy).
} 
written off or sold. ${ }^{12}$ The bad debt write-off rate varies significantly across the major banks, with banks with the highest NPL ratios featuring the lowest write-off rates (Figure 6).

\section{The slow pace of write-offs is an} important factor in the rapid buildup of NPLs. Write-offs ${ }^{13}$ or sales to third parties are one of the most efficient and quickest means of removing bad assets from banks' balance sheets. Italian banks, on the other hand, tend to hold on to NPLs, while pursuing internal collection and loan

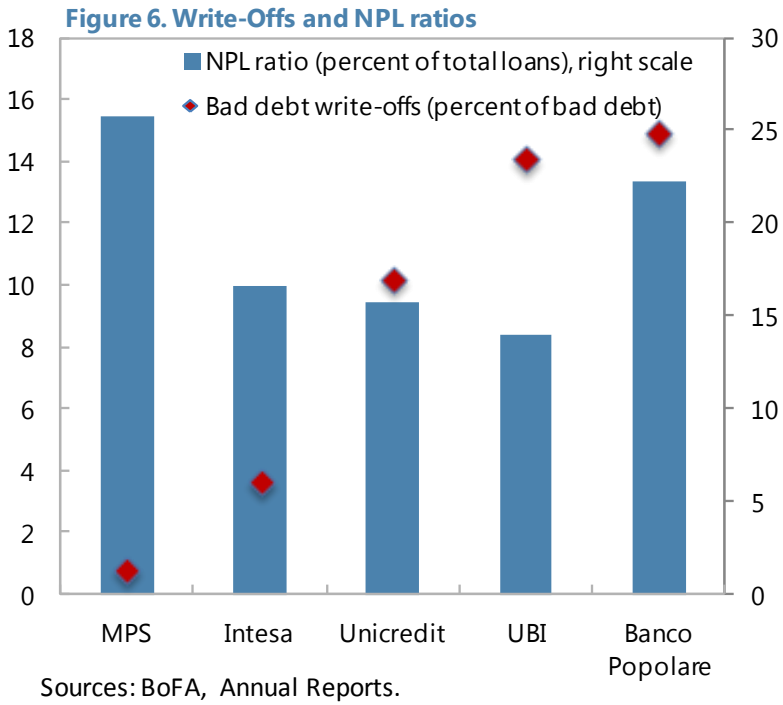
restructuring efforts. In normal downturns, this strategy has allowed banks to gradually reduce NPLs as the flow of new bad debt declines with the recovery. However, with the prolonged recession, the inflow of new NPLs has remained high while write-off rates have not increased significantly, leading to a large backlog of bad debts.

\section{Implications of the Slow Pace of Write-offs}

\section{Without a significant pickup in write- offs, NPLs will remain high for a prolonged period. Staff simulations} suggest that at the current write-off pace and assuming a modest decline in default rates next year, the bad debt ratio would peak only in 2019 and decline gradually thereafter. In the absence of a stronger recovery, it will take a substantial increase in write-offs (and sales) — nearly five times compared to the current rate - to bring down the bad debt ratio to pre-crisis levels within ten years (Figure 7), highlighting the significant challenge in addressing the huge backlog created by the slow pace of write-offs.

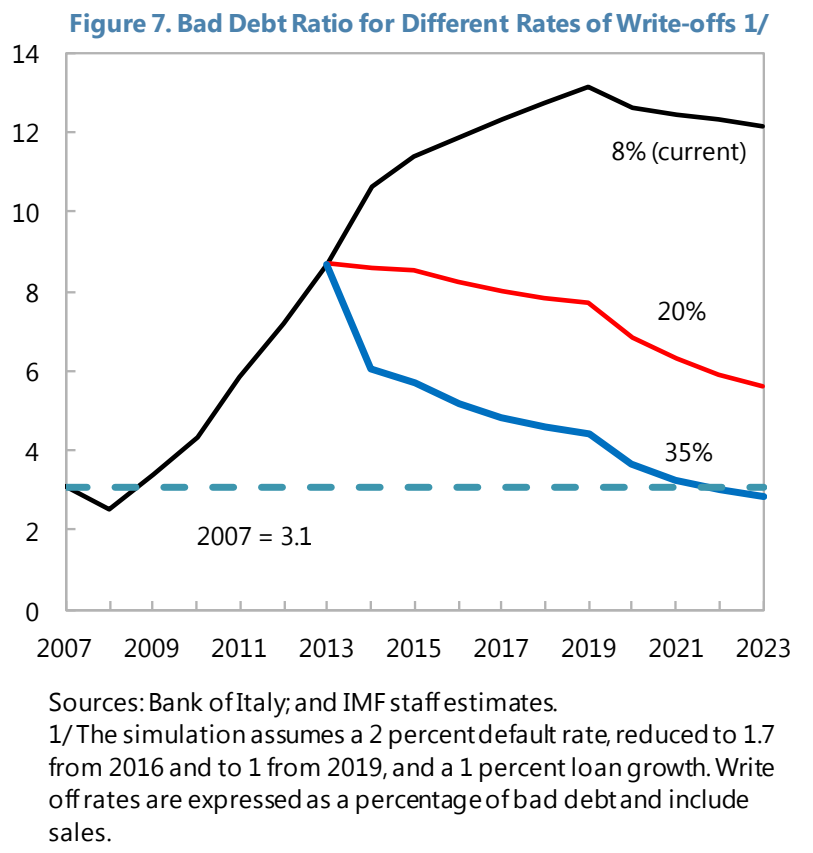

\footnotetext{
${ }^{12}$ In 2013, the bad debt write-off rate was 7.7 percent, including sales of NPLs.

${ }^{13} \mathrm{~A}$ loan that is written off is removed from the balance sheet, while a loan that is written down (provisioned) is still on the

balance sheet, albeit at a lower value net of impairments (provisions), with a possibility to recover the initial value.
} 
High NPLs depress bank profitability and constrain new lending. On the revenue side, NPLs generate a "negative carry," as they do not produce cash interest revenues, yet require funding at market rates. This in turn pushes up interest rates on performing loans to compensate for the lost revenue. Holding NPLs also tie up human and operational resources and involve legal and administrative costs, which could be used to support new investment. NPLs, even if adequately provisioned, also absorb valuable bank capital which if released, could support fresh lending. For example, staff estimates of the capital cost for NPLs (as high as 6 percent of capital for the largest bank) suggest that selling the bad debt portion of NPLs, i.e., those already in insolvency and are full provisioned, could free up significant capital to support new loans (Box 1).

\section{Box 1. Calculating the Cost of Capital for Holding Nonperforming Loans}

In large Italian banks, NPLs, even if adequately provisioned, absorb valuable bank capital.

Calculating the cost of capital for holding NPLs depends on the credit risk approach:

- For banks using standardized methods, the capital charge for NPLs amounts to 12 percent of risk weighted assets but only applies to NPLs that are inadequately provisioned or not collateralized. Most mid-sized and all small Italian banks follow standardized methods.

- Under the internal ratings-based models, the capital charges on NPLs depend on the risk approach.

- $\quad$ For banks under the Basel II IRB Advanced (IRBA) approach, the capital cost for NPLs is twofold: (i) a capital deduction for the provision shortfall between Basel II expected losses and IFRS accounting provisions. This capital deduction is known as the "IRB shortfall," and (ii) a capital charge for gross NPLs (i.e., even if adequately provisioned), based on banks' internal models. All large Italian banks (UCG, ISP, MPS, Banca Popolare, and Ubibanca) are under the IRBA approach.

- In contrast, banks under the IRB foundation (IRBF) approach are only required to deduct the "IRB shortfall." There is no other capital charge on NPLs. In Italy, only two mid-sized banks follow IRBF methods.

Based on the example of the largest Italian bank, NPLs are estimated to tie up more 6 percent of capital and if sold, could free up significant resources for new lending. The capital cost of holding NPLs can be approximated through the recent disclosure on noncore assets (NCAs) by the largest Italian bank, UCG. In June 2014, UGC reported $€ 81$ billion of NCAs absorbing $€ 2.7$ billion of capital, i.e., 6 percent of UCG's CET $1 .{ }^{14}$ If the bad debts from the NCAs were sold at book value,${ }^{15}$ the capital released could amount to $€ 1.6$ billion, possibly supporting up to $€ 56$ billion in new lending.

Sources: Basel Committee on Banking Supervision The Internal Ratings-Based Approach Supporting Document to the New Basel Capital Accord, 2001; UniCredit, "UniCredit Group: Guidelines of Strategic Plan 2013-18," and "Fixed income presentation," December 2014.

\footnotetext{
${ }^{14}$ NCAs include bad debts and problem loans, i.e., performing loans with higher risk. They absorb $€ 33.4$ billion of RWAs. One third of UGC's NPLs is not reported as NCAs, therefore not included in this capital calculation. Hence, it represents a low base estimate for large banks.

${ }^{15}$ The calculation is made under the assumptions that the high provisions on bad debt would not imply further losses. When there is pricing gap, the capital releases may be less (see part III).
} 
High NPLs also lower bank valuations and increase the cost of funding. Weak asset quality may be an important factor in explaining Italian banks' higher CDS spreads and lower market valuations compared to banks in the rest of Europe and the United States (Figure 8). Because probabilities of default and loss given default are highly correlated, higher NPLs in an economic downturn lead to lower recovery values and larger credit losses. There is also empirical evidence that banks with worse asset quality are more sensitive to sovereign distress, ${ }^{16}$ pushing up risk premia in the real economy. High levels of NPLs exacerbate this sensitivity by raising the range surrounding possible future losses.

\section{The slow pace of write-offs in Italy stands in} contrast with other countries that have experienced a rapid buildup in NPLs. For example, after U.S. banks' NPLs peaked at 5 percent in 2009, provision and write-off rates rose quickly, helping to push U.S. NPL ratios to below their pre-2008 levels within 3 years (Figure 9). Similarly, in Japan after its banking crisis, aggressive supervisory policies helped reduce the NPL ratio of major Japanese banks from 8.5 percent in 2000 , to below 2 percent in 2005 (see Box 4). In contrast, NPLs in Italy and the euro area as a whole continue to rise, reflecting in part slow write offs and sales.

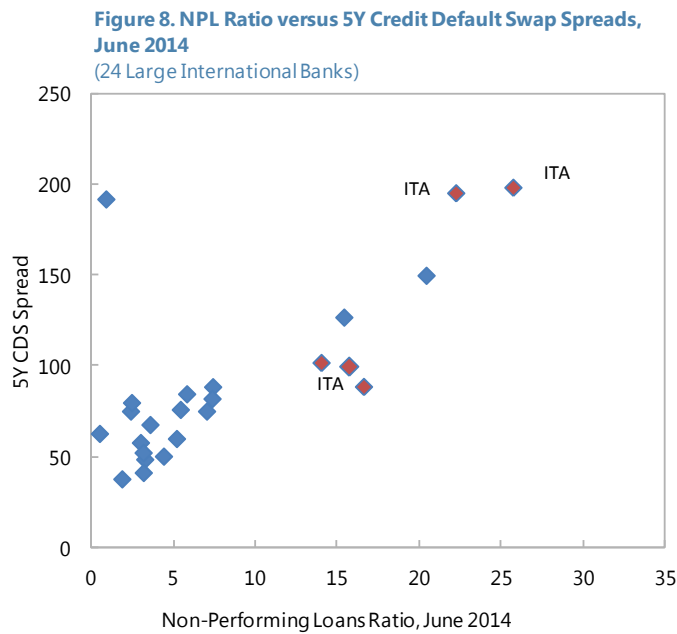

Sources: Bloomberg; and SNL.

Note: The sample involves 24 large intemational banks across the United States and the EU.

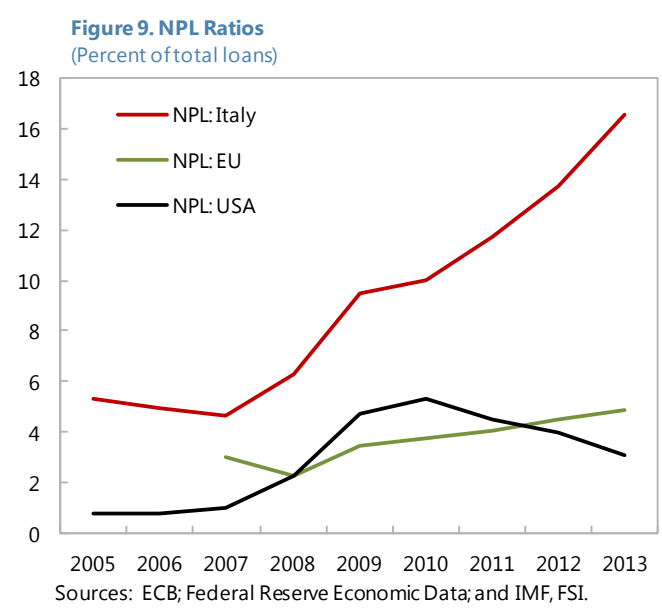

\section{Reasons Behind the Slow Pace of NPL Resolution}

Both supply and demand factors are behind the slow pace of NPL resolution. Factors limiting supply relate to the limited incentives for banks to write off and sell NPLs. Low provisioning of problem loans represents a significant obstacle, leading to large gaps in pricing. Other impediments include limited capital to absorb further losses, the accounting treatment of the write-offs under IFRS, and a tax regime that tends to penalize aggressive provision and write offs. On the demand side, the slow pace of NPL resolution is held back

\footnotetext{
${ }^{16}$ On sovereign distress and bank funding, see CGFS 43, The impact of sovereign credit risk on bank funding conditions", July 2011.
} 
by a lengthy and inefficiency judicial system and the lack of a secondary market for NPLs.

\section{A. Supply Factors: Limited Incentives for Banks to Sell and Write Off}

\section{Low provisions and capital buffers}

Low provisioning for problem loans has led to large pricing gaps that have held back write-offs and sales. When provisioning is too low, write-offs generate losses that are immediately taken out of bank capital. Similar to writing off, selling NPLs would imply some discount compared to book valuations, if investors perceive current provisioning as too low. Depending on the type of loans, this NPL "pricing gap" between book and market values is reported to be around 15-20 percent and to have narrowed recently, partly as a result of the BoI's special inspections in 2012 and the European AQR. The pricing gaps also partly reflects different provisioning rates for the same borrower across banks, which can lead to creditor holdout problems when trying to sell distressed loans.

Banks also face the incentive to hold on rather than dispose of provisioned loans to boost their overall provisioning coverage ratios. The provisioning ratio is defined as cash provisions to gross loans and is a commonly used indicator for assessing credit risk. Putting aside the benefits of disposing NPLs, writing off bad loans that are highly or fully provisioned reduces the provisioning coverage ratio by lowering gross loans (the denominator) more than level of provisioning (the numerator). ${ }^{17}$ In normal times when NPLs are low, banks may be indifferent to the impact of NPL disposal on their coverage ratios. However, when NPLs are high and coverage is low, banks may face strong market pressure to maintain their provisioning coverage ratio and hold on to highly provisioned loans, rather than disposing.

Capital buffers remain thin to absorb future credit losses. The low level of sales and write-offs may also reflect banks' limited buffers to absorb further losses. As of December 2013, 13 out of the 15 large Italian banks had a CET1 ratio below their Euro Area peer average (11.4 percent). ${ }^{18}$ Moreover, the ratio of unprovisioned NPLs to capital and reserves - the socalled "Texas ratio" — stood at around 90 percent in June 2014, well above those of other EU countries (Figure 10), highlighting Italian banks' vulnerability to further credit losses. ${ }^{19}$

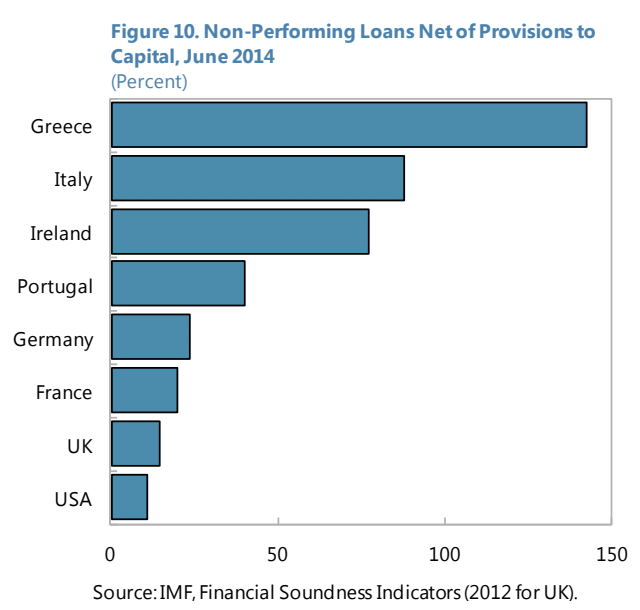

\footnotetext{
${ }^{17}$ For instance, assuming a bank has half of its bad debt provisioned at 60 percent and the other half at 20 percent, its average provisioning ratio would be 40 percent. If the bank was to write off or sell the 60 percent provisioned debt, its provisioning ratio would fall to 20 percent.

${ }^{18}$ ECB, October 2014. Since January 2014, the large Italian banks have raised capital; their weighted capital CET1 ratio reached 11.5 percent as of end-June 2014.

${ }^{19}$ The "Texas ratio" has been used as crude measure of a bank's likelihood of failure by comparing its bad assets to available capital and reserves. A ratio above 100 percent indicates that banks have insufficient cash to cover fully losses on
}

(continued...) 


\section{Heavy reliance on collateral and close relationships with borrowers}

Bank's reliance on collateral also limits the incentives to write-off or sell. Italian banks remain heavily reliant on collateral, covering over two-thirds of loans, mainly in the form of personal guarantees or real estate. ${ }^{20}$ While collateral provides added security against losses, it also encourages banks to wait and collect at the end of foreclosure rather than to dispose immediately. In other words, with paid collateral providing coverage against further losses, banks possess a "zero-cost call option" to wait for the loan value to recover. Selling collateral at below book value could also lead to the re-pricing of other similar collateral and lower further banks' overall provision coverage.

\section{In addition, disposing of loans based on long standing relationships may pose} reputational risks. In general, relationship-based lending reinforces banks' ability to assess the creditworthiness of borrowers, especially SMEs, and address information asymmetry issues by relying on "soft" information gathered by loan officers, through continuous, direct contacts with the owners and managers, and the local community in which they operate. Aggressive NPL disposal may undermine banks' business reputation and model, raising the cost for early NPL disposal and the likelihood of a more drawn out resolution process.

\section{Box 2. The European Central Bank's Balance Sheet Assessment and Results for Italy}

In October 2014, the ECB published the results of the comprehensive Balance Sheet Assessment (BSA). This exercise, performed by the ECB in cooperation with the national supervisors, reviewed the balance sheets of 130 Euro Area banks, of which 15 were Italian banks.

Methodology. Based on year-end 2013 accounting data, the comprehensive BSA included two steps:

- An Asset Quality Review (AQR), which assessed the adequacy of provisions and collateral valuations.

- A baseline and an adverse stress test scenarios, over a three year horizon (2014-2016).

Under the AQR and the baseline scenario, the banks' capital adequacy was evaluated against an 8.0 percent common equity capital threshold, and under the adverse scenario, a requirement of 5.5 percent.

\section{Results for Italian banks:}

Capital. The results highlighted $€ 9.7$ billion of capital shortfall for nine Italian banks out of the 15 under review (December 2013). After accounting for the capital increases undertaken between January and September 2014, the capital shortfall applied to only four banks, amounting to $€ 3.3$ billion.

Provisioning. The AQR disclosed an average discrepancy of 10 percent ${ }^{21}$ on gross NPE, based on the sample of audited loans. For 11 banks, more than one fifth of the exposure was not performing (Figure 11).

their bad loans. The ratio was developed in the late 1980s and early 1990s to gauge the likelihood of bank failure in Texas. In 1989, more than 20 percent of the banks in Texas had a ratio that exceeded 100 percent, leading to more than 130 failures.

${ }^{20}$ According to the Credit Register data, one quarter of corporate loans are backed by real estate collateral, with the remaining security in the form of personal guarantees.

${ }^{21}$ BoI Financial Stability Review, November 2014. This figure is about half the corresponding figure for the entire SSM. 


\section{Tax disincentives to provisioning and write-offs}

The tax regime in Italy tends to penalize banks that aggressively provision and write off their NPLs. Until recently, write-offs in Italy were not tax deductible without a court declaration of insolvency, which could take several years. Banks were allowed to deduct loan-loss provisions from taxable income only up to 0.3 percent of outstanding loans. The remaining provisions were treated as a deferred tax asset (DTA) that could be deducted from taxable revenues in equal installments over 18 years but at a lower net present value. The cap on tax deductibility was a disincentive for banks to provision their bad loans more aggressively. The law was changed in 2013 and now allows provisions and write-offs to be deducted in equal installments over five years with a higher tax rate (including the regional tax IRAP). ${ }^{22}$ This is still more restrictive than in most other countries, but compared to the past, provides greater incentives for banks to provision.

Public agency's priority status in bankruptcy may also deter banks from initiating debt restructuring or pursuing liquidation. Tax authorities like other public debtors (social security) in Italy benefit from a higher priority claim than other unsecured creditors in bankruptcy procedures. For firms that have accumulated large public arrears with preferred creditors, this may diminish banks' incentives to pursue bankruptcy procedures on borrowers.

\section{Accounting regime favorable to holding NPLs}

The lack of accounting guidance under IFRS lengthens NPL write-offs. Similar to other European banks, banks in Italy base their financial reports on IFRS, where the current rules (IAS 39) do not specify when and how to write off uncollectible loans. ${ }^{23}$ In the absence of clearly defined write-off rules under IAS 39 , some banks ${ }^{24}$ follow the rules for loan cancellation (derecognition), which require banks to exhaust all legal means or give up contractual rights on the loans before removing them from the balance sheet. ${ }^{25}$ The new norm (IFRS 9), which comes into effect in January 2018, will include a definition of "writeoff" that is different from loan cancellation and will reinforce the current guidance from BoI.

The accounting approach to accrued interest allows banks to overstate earnings on NPLs. As IAS 39 permits interest on impaired loans (NPLs) to be accrued on certain categories of NPLs, banks continue to recognize uncollected interest income even though the borrower is unlikely to repay either the principal or the interest of the loan. This accounting

\footnotetext{
${ }^{22}$ See A. De Vincenzo and G. Ricotti, "The use of tax law from a macroprudential perspective," http://www.bancaditalia.it/pubblicazioni/note-stabilita/2014-0001/index.html.

23 "Supervisory Roles in Loan Loss Provisioning in Countries Implementing IFRS," WP/14/170, Ellen Gaston and In Won Song.

${ }^{24}$ This should in principle be mitigated by the general guidance provided by the BoI according to which write-offs take place when the management formally acknowledges the impossibility to collect the loan or part of it. However, some banks may have implemented laxer write off policies, limiting them to the loan cancellation.

${ }^{25}$ The derecognition rule was designed for specific events, such as the sale or transfer of financial instruments.
} 
treatment thus overstates interest income as well as banks' provisioning ratio, providing a strong incentive for banks to retain old NPLs that have accrued a large amount of uncollected interest (Box 3).

\section{Box 3. How Does the Accounting Approach to Accrued Interest Disincentivize Write-offs?}

Accrued interest under IFRS tends to overstate the interest income and to unduly boost provisioning ratios, discouraging banks from writing off NPLs. ${ }^{l}$

According to IAS 39, loans classified as NPL continue to include interest in the estimated future cash flow provided that the banks consider them recoverable based on historical collections (this is not the case for bad loans, the so-called "sofferenze"). ${ }^{26}$

Mechanism. When accrued (uncollected) interest on NPLs is reported as income, bank's true profits are overstated. To compensate for this impact on profits and capital, accrued interest is offset by an opposite accounting entry, i.e., a 100 percent provision. This accounting entry, however, adds to the stock of outstanding provisions (numerator), while increasing the size of assets that are not likely to be recoverable (denominator). As a result, the accounting of accrued interest overstates the calculations of banks' provisioning ratio.

Illustration. In year 1, a bank holds 100 of NPLs, provisioned at 55 percent. In year 2, the accrued interest is calculated at 1 and is provisioned at 100 percent. The total stock of provisions becomes 56 and the total NPLs becomes 101 . The provisioning ratio has mechanically increased by half a percent, from 55 to 55.5 percent. Over years, this effect cumulates and can overstate the actual improvements in provisioning.

1/Accrued interest on "NPLs" accounted for $€ 4.3$ billion in December 2013, i.e., around 10 percent of the net interest income. Banks do not accrue interest on bad loans (loans in state of insolvency).

\section{B. Demand Factors: High Cost and Limited Options for Restructuring}

\section{A lengthy and inefficient judicial process}

\section{The lengthy inefficient judicial process raises the cost of foreclosure and lowers the} return on NPL restructuring. By various measures, performance and efficiency of the Italian justice system is well below the European and OECD averages. For example, it takes on average more than seven years to complete a bankruptcy procedure and three years to foreclose on real estate collateral. According to the World Bank Doing Business surveys, Italy ranks low in resolving insolvency (\#20 out of 31 OECD countries) and in enforcing contracts (\#30 out of 31). Legal uncertainties and a lengthy foreclosure process limit the options for and drive up the cost of restructuring.

\section{Despite improvements in the insolvency law, the large backlog of cases continues to rise.} Since 2005, various amendments to the insolvency system have allowed for both out-of-court restructurings ${ }^{27}$ and court-led alternatives, such as composition with creditors. In 2007, the authorities introduced a U.S. Chapter 11-like procedure (Concordato preventivo) that a growing number of distressed firms have used. ${ }^{28}$ Despite these improvements, the pace of

\footnotetext{
${ }^{26}$ Detailed Assessment of Observance of Basel Core Principles for Effective Banking Supervision, December 2013, page 120 .
} 
insolvency remains slow. With the number of defaults having doubled during 2007-13, the large backlog of cases (estimated at around 9.7 million in 2012) continues to grow and hold back NPL resolution. ${ }^{29}$

Debt restructuring is also limited under the legal framework. For example, debt-equity swaps, where the lender, usually a bank, reduces the borrower's debt against an equal value of new shares, are an important instrument in corporate restructuring. However, under the Italian legal system, debt-equity swaps are effectively limited to restructuring under the Concordato preventivo procedure which allows for cram down of dissenting creditors. In out-of-court workouts, debt-equity swaps are possible but only on a consensual basis (with no cram down). Even out-of-court enforcement of share pledge agreements is in practice little used due to potential legal challenges by shareholders for the enforcing banks. ${ }^{30}$

\section{A small investor base with limited risk capital}

A small investor base and lack of equity capital have also limited demand for distressed loans. Banks face inherent difficulties in corporate restructuring, given their traditional lending focus and higher capital requirements under Basel III for holding converted equity. Compared to banks, private equity or restructuring funds are better equipped in terms of risk capital and expertise to undertake debt and operational restructuring of distressed firms. The private equity market in Italy, however, is small, with only around $€ 3$ billion of transactions annually. Institutional investors, such as pension funds and insurance companies, follow a fairly conservative portfolio strategy, with only a small share invested in alternative assets, such as distressed debt.

\section{A Strategy For DeVeloping A MARKet FOR NONPERFORMing LoAns In ItALy}

\section{A. Benefits of a Market for Nonperforming Loans}

\section{For banks, an active market for NPLs would facilitate disposals and support new}

lending. A secondary market for NPLs would reduce the collection burden on banks and free up resources and capital to support new lending. It would also help boost loan recovery values by providing a more cost effective alternative to lengthy court procedures. A liquid

\footnotetext{
${ }^{27}$ Out of court mechanisms are represented by the "reorganization plans" and "debt restructuring agreements."

${ }^{28}$ The Concordato Preventivo is a restructuring instrument through which the debtor can agree on a plan with creditors (subject to a vote) to avoid bankruptcy. The procedure also grants an automatic stay against enforcements and precautionary judgments (60 to 180 days), similar to the U.S. automatic stay, during which the debtor remains in possession and continues to run the business.

${ }^{29}$ IMF WP 14/32, "Judicial System Reform in Italy-A Key to Growth", G.Esposito, S.Lanau, and S.Pompe.

${ }^{30}$ When banks benefit from a share pledge agreement over the borrower, such a pledge can be used to force a debt-equity swap in a distressed scenario (for instance, when a firm has a negative equity). However, in practice such a pledge is difficult to enforce as there is no clear law and guidelines. Moreover, any enforcement process can be challenged, for instance, by arguing it does not maximize the value of the shares, and as a consequence implying a damage for the existing shareholders. See also Linklaters LLP, Insight and Foresight, "Navigating the European Loan Portfolio Market."
} 
secondary market for distressed debt (and foreclosed collateral) would also enhance bank risk management by providing another instrument to manage credit and market risks. Over time, such a market could become a standard operational tool for Italian banks for offloading bad assets and reorienting their loan portfolios.

\section{Box 4. Japan's Experience with Distressed Loan Markets}

Starting in 1991, the collapse of the Japanese financial bubble lasted for more than a decade, with plummeting asset prices resulting in high bank NPLs. In 2001-2002, the government took emergency measures to simultaneously resolve the NPLs and corporate overhang. These measures had positive effects on financial stability, with the NPLs reduced by more than a half in less than five years.

In 2001, the Japanese government outlined a strategy for addressing the NPL problem in the banking system. The strategy called for major banks to accelerate the disposal of NPLs from their books within three years after their recognition. Banks were expected to remove these loans either by selling them directly to the market, pursuing bankruptcy proceedings, or by rehabilitating borrowers through out-of court workout procedures. Any remaining loans were to be sold to the Resolution and Collection Corporation (RCC), which under the Financial Reconstruction Law had been given new powers to purchase distressed assets at fair market value and to restructure companies.

The centralized AMC was given special powers. $\mathrm{RCC}$ is a government-owned agency that was 100 percent owned by Deposit Insurance

Corporation. Between 1999 and mid-2002, it acquired $¥ 55$ trillion ( $\$ 495$ billion) in face value loans at a purchase price of $¥ 1.3$ trillion (96 percent discount). The law expanded its mandate to securitize NPLs, rehabilitate troubled firms and participate in debt-equity swaps. It was entrusted with special investigative powers that allowed it to tackle difficult cases, such as real estate tied to organized crime for banks that had been unable to collect or sell bad loans. The RCC could take on difficult assets that other investors are unwilling to touch and help resolve intra-creditor dispute and strengthen the leverage in negotiating with the debtors. The RCC also improved the transparency of the NPL market by setting standards of disclosure and publishing information on collateral.

In a second step, the government shifted the supervisory emphasis to exiting nonviable corporates and restructuring viable ones. The FSA tightened the collateral valuation for nonviable borrowers by requiring banks to mark down collateral to market prices. This induced banks to sell their real-estate collateralized loans, which in turn created a market for distressed collateral sales. In the beginning, since the number of active investors was very limited, transactions were executed on a bilateral basis, at low prices. As the number of investors increased and as the banks improvised on using auctions in their collateral sales, the returns to investors decreased. Japanese buyers gradually replaced foreign investors. The government announced the Financial Revitalization Program to promote corporate debt restructuring for large firms (2002). The FSA tightened loan assessment standards for large borrowers, using market information such as stock prices, credit ratings and discounted cash flow analysis to evaluate the viability of the underlying corporates. This led banks to reclassify part of their portfolio to sub-performing and sell them.

Sources: Kazunari Ohashi and Manmohan Singh, "Japan's Distressed Debt Market,” IMF WP/04/86, May 2004; Japan's Lost Decade, Policies for Economic Revival, Tim Callen and Jonathan D. Ostry. 


\section{A market for NPLs would also support corporate restructuring and expand sources of} financing. An active market for NPLs would improve secondary market liquidity for loans and attract a wider range of institutional investors, such as private equity funds, asset managers, insurance companies, and pension funds, including from overseas, to assist in corporate restructuring. These institutional investors could help expand nonbank sources of financing and provide another source of needed capital for the corporate sector. ${ }^{31}$ In the near term, a market for NPLs could support a faster recovery by facilitating the exit of nonviable firms and supporting the growth of viable ones. Over time, a distressed debt market could help promote more broadly the reallocation of resources towards more productive corporates and assist in their reorganization and expansion.

\section{B. Current State of the Distressed Debt Market}

\section{Despite the buildup in NPLs, a market for restructuring distressed debt in Italy has yet} to pick up after the global financial crisis. Compared to the large size of NPLs

( $€ 333$ billion), the market for distressed debt remains small in Italy, with NPL sales of only around $€ 2-3$ billion in 2012-13 (PwC). ${ }^{32}$ In Italy, sales accounted for only 1 percent of bad debts in 2013 and were concentrated mainly on highly provisioned loans, whose values had already been fully discounted without risk of further loss. According to market participants, these sales involved loans that defaulted more than 10 years ago (before the global financial crisis). Reflecting the paucity of domestic players, buyers of Italian NPLs are mostly AngloSaxon hedge funds and private equity funds, while the main sellers have been large Italian and foreign-owned banks (Figure 13).

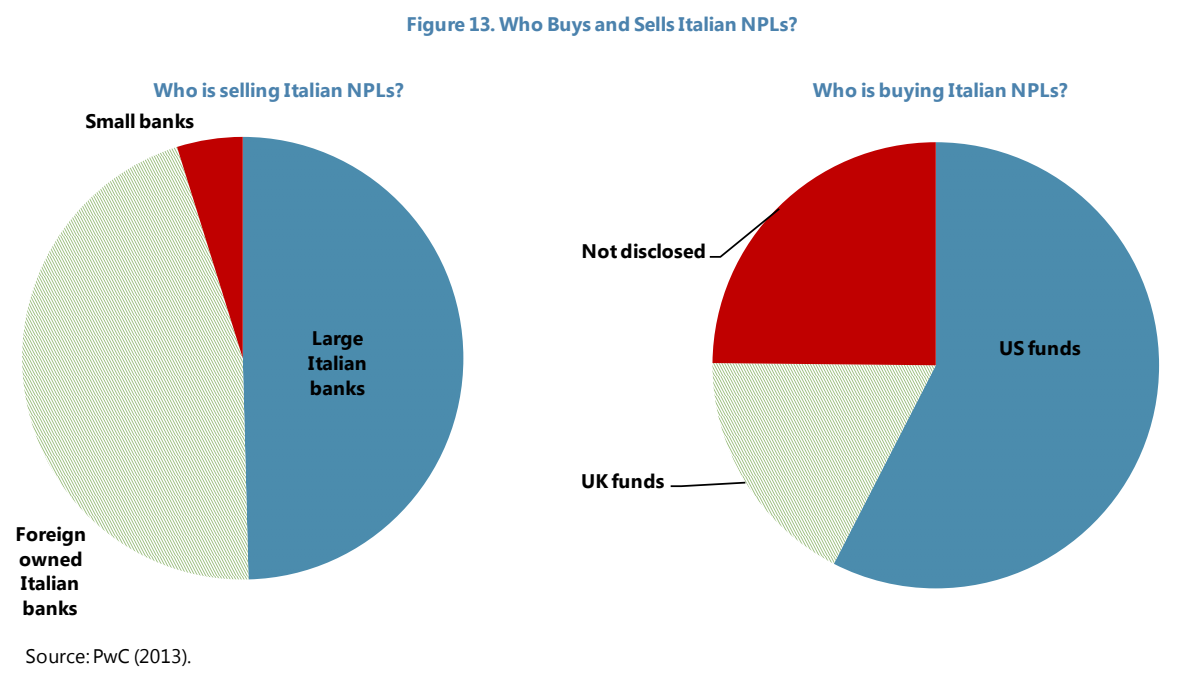

\footnotetext{
${ }^{31}$ For example, for Italian banks' bad debt, which is already in a state of insolvency and fully provisioned, writing off or converting bad debt to equity (even partially) could reduce the indebtedness of the Italian corporate sector by as much as $€ 106$ billion ( 8 percent of GDP), improving the capital position of corporates with little further losses for the banks. However, it would also lower the provisioning ratio from 42 to 15 percent.

${ }^{32}$ For the first half of 2014 , PwC reported $€ 2.5$ bn (public transactions).
} 
A market for securitizing NPLs also exists, and in past recessions (1996-2000), was used extensively by Italian banks to dispose of NPLs. For example, in 2000, 50 percent of assetbacked securities (ABS) issued by Italian banks in 2000 was for NPL disposal the figure fell to 20 percent over $2001-05 .{ }^{33}$ However, with the collapse in securitization after the financial crisis, Italian NPL-ABS issuances have also dried up, with ABS issuance now concentrated on the highest quality securities for the purposes of collateralized ECB borrowing.

\section{In Italy, initiatives to set up private AMCs and restructuring vehicles are slowly} emerging. Since December 2013, UCG closed two deals for about $€ 2$ billion and has been negotiating a partnership with ISP to set up a special purpose vehicle (SPV) with outside investors (see Box 5), and a sale of its servicer disposal platform for about $€ 2.5$ billion. ${ }^{34}$ In June 2014, MPS sold $€ 0.5$ billion of NPLs to Fortress. In May 2014, Banca Popolare, the fifth largest Italian bank, also announced its intention to sell a large portfolio of NPLs and properties ("Release") for a net book value of $€ 3.2$ billion. ${ }^{35}$ In contrast, NPL activity by smaller banks has been very limited.

\section{Box 5. UniCredit and Intesa Partnership Initiative with Kohlberg Kravis Roberts and Alvarez \& Marsal}

In April 2014, UCG, ISP, KKR, and A\&M signed a memorandum of understanding to jointly develop and implement a vehicle that optimizes the performance of a selected corporate loan portfolio under restructuring through proactive management and additional funding. This new vehicle is expected to kick off in 2015.

No risk deconsolidation. ISP and UCG will retain a material interest and will not deconsolidate their shares in the vehicle.

Limited amounts but open structure. The vehicle will target the corporate loans that the two banks have in common and for which they are the primary banks (for instance, granting more than 50 percent of the loans). The objective is to obtain control of these corporates through debt equity swaps and new equity in order to restructure them. The vehicle will start with a limited number of loans (estimates of $€ 2$ billion, about 1.5 percent of gross NPLs of both banks). In the future, the vehicle could be opened to other banks that have common exposures.

Profit sharing. The original banking claims will be ranked junior to the new financing provided by the KKR. There will be a profit sharing agreement, with KKR earning a fixed annual return as well as a percentage of the upside gains.

The distressed debt market in Europe is small but has also shown signs of picking up. Compared to the United States where a market for NPLs has existed since the late 1980s and amounts to around $\$ 400-450$ billion in transaction per year, the market in Europe is still in the early stages. NPL sales in Europe are estimated to have risen from $€ 11$ billion in 2010 to

\footnotetext{
${ }^{33}$ The domestic accounting standards in force at that time alleviated the transfer cost, as it allowed banks to deconsolidate at net book values, while recognizing the market losses over five years. Such schemes would not be compliant with IFRS and thus could not be undertaken today. From 2001 to 2005, nearly $€ 26$ billion of bad loans were securitized.

${ }^{34}$ Due to difficulties in reaching a price agreement, press reports a smaller sale than initially anticipated in May 2014 (from $€ 3-4$ billion to $€ 2.5$ billion).

${ }^{35}$ Press reports delays due to difficulties in reaching a price agreement.
} 
over $€ 64$ billion in $2013 .^{36}$ Most of the activity has taken place in Germany, Ireland, Spain, and the United Kingdom and focused mainly on commercial real estate and consumer loans. The main factors behind its recent growth include: increased sales of defaulted loans, tougher regulation, especially under the ECB's comprehensive assessment, ample liquidity, improving sovereign risk, and growing interest from overseas investors seeking higher yields (Figure 14).

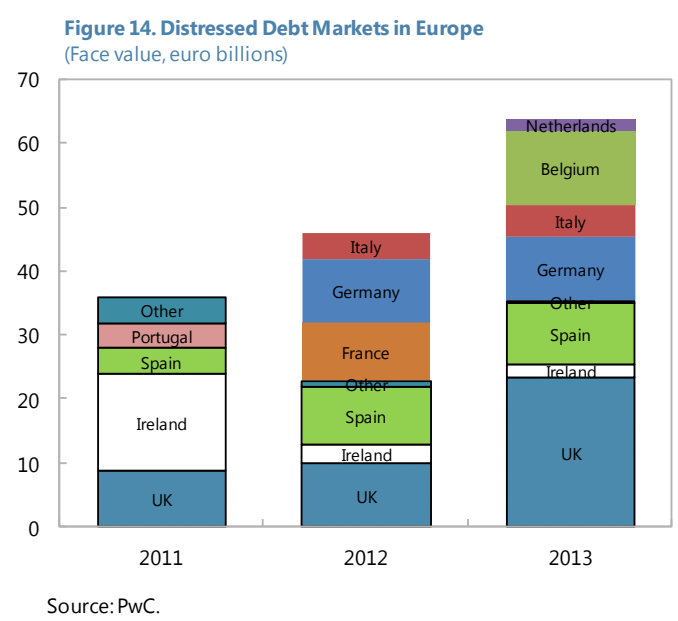

C. Strategy for Fostering a Market for Nonperforming Loans

A strategy for developing a market for NPLs in Italy should look to remove impediments to restructuring and enhance the incentive for banks to sell. Here, the priorities would be to: (i) tighten supervisory policies on provisioning and write-offs to speed up NPL resolution and restructuring; (ii) remove tax and regulatory impediments to debt restructuring; and (iii) improve further the insolvency framework and encourage more out-ofcourt workouts. Finally, facilitating the creation of NPL AMCs and corporate restructuring vehicles would give banks more instruments to restructure, while expanding financing for distressed firms.

\section{Supervisory policies to speed up NPL resolution and debt restructuring}

Stricter supervisory guidelines on loan provisioning would accelerate write-offs. As recommended by the 2013 Italy FSAP, supervisory guidelines on provisioning would promote harmonization of provisioning practices. ${ }^{37}$ For example, several European countries, such as Ireland, have overlaid their accounting standards with guidelines on provisioning. Where legally feasible, other countries have introduced a stricter approach. For instance in Malta, banks are required to build up additional capital for NPLs equal to $2 \frac{1}{2}$ percent of banks' NPLs less IFRS impairments and accrued interest. In 2012, Bank of Spain (which is also the accounting setter) required restructured loans to be provisioned by 15 to 25 percent.

As tried in other countries, supervisors could also tighten supervisory requirements to speed up write-offs. Measures such as imposing higher capital charge or a time-limit on NPL write-offs ${ }^{38}$ (Box 6), as currently done in the United States on mortgages, could put

\footnotetext{
${ }^{36}$ See Ernst \& Young, "European Non-Performing Loan Report 2011” and "Flocking to Europe: Ernst \& Young 2013 NonPerforming Loan Report."

${ }^{37}$ For a broader discussion, see the WP/14/170 (referenced in footnote 20).

${ }^{38}$ A time-limit for NPL write off should be combined with a parallel strategy for addressing the length of judicial proceedings in order not to penalize banks. As a first step, such a time limit could be set at the average lengths for foreclosure or bankruptcy and be further reduced over time. The objective could be to remove from bank balance sheets very old NPLs, older than 5 years.
} 
further pressure on banks to dispose of bad loans. ${ }^{39}$ Japan in 2001-05 also imposed a time limit on NPLs to oblige banks to clean their balance sheets following the financial crisis. Spain also required in 2012 a full write-off of unsecured NPLs classified as "doubtful" after a set period of provisioning. Ending the practice of accruing interest on NPLs for prudential purposes would also remove an important disincentive for banks to write off bad loans. ${ }^{40}$

\section{Box 6. International Practices for the Write-off of Nonperforming Loans}

In the United States, regulators have overlaid the accounting standard with detailed regulatory guidance that harmonizes the treatment of write-offs. The regulators acknowledge that management will have discretion in judging write-offs under U.S. generally accepted accounting principles. But to guide management, regulators have added detailed regulatory guidance that harmonizes the treatment of write-offs. Compliance with the guidance, in turn, is validated through onsite inspections.

U.S. regulatory guidance has introduced time-limits on writing off NPLs that are independent from the time needed to foreclose. For example, after 180 days past due, a mortgage loan is valued exclusively based on the underlying collateral (at market price with no adjustment for possible increase in value over time). Any loan balance that exceeds the value of the collateral, less the cost to sell, should be written off. This requirement is regardless of how long it takes to foreclose.

Guidance on write-offs has also been introduced in other countries to help clean bank books from legacy assets. For instance, in Japan, the emergency economic measures of 2001 further accelerated the disposal of distressed collateral. ${ }^{1}$ A guideline required major banks to remove near-bankruptcy and lower quality loans ("bad debt") within three years after their recognition. This helped remove a book value of old loans worth 270 billion USD from bank balance sheets from 2001 to 2004. In Brazil, distressed loans (so called "H" loans) must be written off after six months. They continue to be accounted for off-balance sheet, provisioned at 100 percent. Smaller Latin American countries, like Guatemala, also apply rules on write-offs for consumer loans.

Sources: "The U.S. mortgage crisis: Are There Lessons for policymakers?" Michael Fratantoni and Michael Moore, February 2013; FDIC Risk Management Manual; IMF WP/04/86, Basel Core Principles for Effective Banking Supervision-Detailed Assessment of Compliance for Brazil and Japan, 2012.

${ }^{1}$ This temporary measure was withdrawn in 2005 after the stock of NPLs had declined substantially and the banking system was officially regarded as "normalized." Instead, a new guidance was issued to continue to encourage early identification and disposal of bad debt.

To help address the corporate debt overhang, supervisory policies should facilitate the liquidation of nonviable firms. Delays in placing nonviable firms in insolvency remain an issue in Italy and many other European countries. Bad debt (in a state of insolvency) in Italy accounts for more than half of NPLs and is concentrated mainly among medium and large firms (Figure 15). As initiated in the ECB AQR, by using stricter impairment triggers and discounted cash flow analysis, supervisors could encourage banks to distinguish more aggressively between viable borrowers (who will continue to generate cash flows to cover interest payments) and nonviable ones that need to be exited. For nonviable borrowers, as

\footnotetext{
${ }^{39}$ As recommended by the IMF WP/14/170, in order to avoid giving up their contractual rights on future recovery proceeds (e.g., collateral), banks need to ensure they have safeguards over loan documents and collection ledgers for loans that are written off but still have legal rights and potential for recovery (as is the case in the United States).

${ }^{40}$ While constraining banks behavior for accounting purposes could raise legal issues due to IAS 39, encouraging banks to disclose their results under both accrual (IFRS) and non-accrual (prudential rules) practices would help users better identify cash versus noncash earnings. This assumes that banks continue to keep the prudential provisioning systems after adopting IFRS (see Section IV.A).
} 
their assets are central to the loan recovery, supervisors will need to include liquidation costs in recovery proceeds to ensure that banks carry the liquidated values on their book.

\section{In past crisis, supervisors have often pushed for swift recognition and exit of nonviable borrowers to restart new} lending. For example, in Sweden (1994), corporate firms with low interest coverage ratios and high leverage were pushed into bankruptcy or liquidation (Box 7). Similarly, in Korea (1998), the supervisor instructed

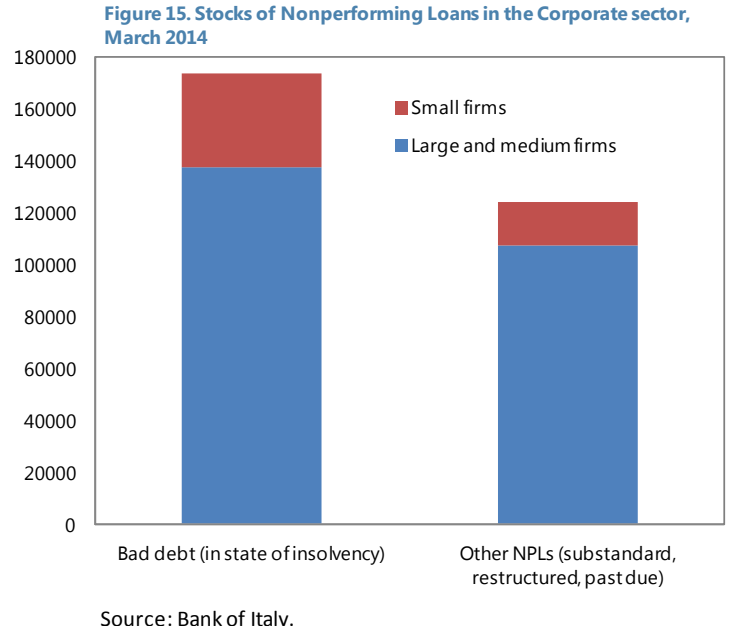

banks to identify nonviable firms, following specific forward-looking criteria and leverage levels. In Japan (2001), the FSA also required major banks to apply strict discounted cash flow analysis in their NPL assessments.

\section{Box 7. The Swedish Approach of Nonperforming Loan Resolution}

The bank resolution policy implemented by the Swedish authorities in the early 1990s is viewed as a model for a more centralized approach to NPL resolution and for avoiding a fire sale of distressed assets and a credit crunch.

The banking crisis (1991-94) was part of a major crisis that hit the Swedish economy. In the mid-1980s, Sweden experienced a lending boom, channeled to asset markets - primarily to housing, as well as to commercial real estate and to the stock market. In 1991, rising international interest rates exerted strong upward pressure on the financial markets, impacting property prices, investment and rising private savings The crisis undermined the financial system and threatened the existence of major banks.

Distressed assets were transferred to centralized AMCs...To address the problems of the weak banks, the authorities split the assets of the ailing banks into "good" and "bad" assets, then transferring the "bad" assets to public AMCs. The largest one, Securum, was set up in 1992, and took on and unwound distressed assets from the state-owned Nordbanken bank.

...where the credits to nonviable firms were either sold or liquidated. Securum took over a quarter of the bank's credit portfolio, i.e., 3000 credits with 1274 companies, of which 790 were listed companies. Companies were categorized based on profitability, interest coverage ratio, and leverage with those deemed nonviable placed in bankruptcy. By mid-1994, 70 percent of the companies held by Securum were declared bankrupt, and were either sold to new owners, or liquidated, with the remaining placed in workout programs.

For the viable firms, Securum pursued corporate debt restructuring programs. Restructuring included changing organizational structures, including replacing management, cutting costs, merging and selling assets, and converting debt into equity to restore profitability. In cases where existing management remained in place, ownership was either diluted or wiped out. To enhance incentives for restructuring, Securum also introduced bonus schemes, including through share buyback options.

Source: "Securum and the Way out of the Swedish Banking Crisis," Clas Bergström Stockholm School of Economics Peter Englund, Stockholms School of Economics and Stockholm Institute for Financial Research, Per Thorell, May 2003.

\section{For distressed but viable firms, banks should propose debt restructuring solutions.}

Bank-led corporate restructuring, such as through partial write-off or debt equity swaps, can provide space for distressed firms to reorganize their business and address their debt problems. Supervisors can assist by having banks apply common guidelines for selecting and 
restructuring distressed, but viable firms. For instance, in Iceland (2010), banks followed harmonized debt restructuring guidelines that fostered creditor coordination and limited holdouts, as well as set quarterly targets for debt restructuring (Box 8).

\section{Enhanced market disclosure would strengthen market discipline and support} supervisory efforts. As initiated by large European banks earlier in the financial crisis (and more recently by UCG), Italian banks should be encouraged to report regularly to their shareholders, progress in disposing NPLs and non-core assets. Banks should also report on asset resolution, debt restructuring and collateral recovery rates to the supervisors. For the weakest banks, the supervisors could set up NPL resolution targets and conduct regular onsite inspections on progress in loan collection.

\section{Regular AQR updates or supervisory inspections should check loan classification and} provisioning across banks. Regular AQRs and inspections will ensure that banks face the proper regulatory incentives to write off bad loans by moving their net book value (after provisions) closer to the market price. As AQRs require data on problem loans, they can also promote a more portfolio approach to NPL disposal, including through asset securitizations or sales. To ensure broad coverage, AQRs should be extended to smaller banks, which may lack capacity and resources for NPL resolution.

\section{Removal of tax and other impediments to loan restructuring}

Remaining tax impediments to timely provisioning should be removed. The 2013 measure to raise the cap on tax deductibility is an important step to improving incentives for provisioning. To reduce the procyclicality of provisioning and level the competitive playing field for Italian banks, the system could go further and allow provisions and write offs to be fully deductible in the same fiscal year as done in other neighboring countries. This would also incentivize banks to more aggressively provision during an economic downturn (and write back these gains during the recovery).

Public agencies with claims on defaulted borrowers should participate in debt restructuring agreement and face similar treatment with other creditors. Public creditors, such as tax and social security authorities should be encouraged and enabled to participate in out-of-court and incourt debt restructurings. Although public agencies' priority status on tax and social security claims are meant to protect state revenue, they may also lower collection and enforcement by reducing incentives for public creditors to participate in debt workouts that could improve recovery. This issue is particularly acute for unsecured loans. ${ }^{41}$ Putting public creditors on the same footing as private creditors would incentive all parties to maximize collection efforts and promote a more orderly resolution of debt difficulties. ${ }^{42}$

\footnotetext{
${ }^{41}$ The priority status of public agencies is large (since it covers also penalties) but comes after secured creditors.

${ }^{42}$ See forthcoming IMF Staff Discussion Note on “Tackling SME Problem Loans in Europe," by Wolfgang Bergthaler, Kenneth Kang, Yan Liu, and Dermot Monaghan (2015).
} 


\section{Legal reforms to promote both court-led and out-of-court restructuring}

Further use of the recently strengthened insolvency regime will enhance its implementation. As the latest insolvency reforms date from 2012, it will be important to see how the legislation works in practice to provide certainty and stability to insolvency practitioners and creditors. Nevertheless, the need to accelerate completing insolvency and foreclosures remains critical.

Here, insolvency reforms would benefit from improving the efficiency of the court system. ${ }^{43}$ The government has proposed a comprehensive package of judicial reforms, whose first pieces were adopted by the Parliament in November 2014. In particular, these reforms aim to reduce by a half the backlog and the length of civil proceedings; introduce a "fast track" procedure and promote out-of-court resolutions, enhance judges' accountability and reduce holidays and summer closure of courts. Further steps to reduce the legal burden and speed up collateral foreclosure would also be helpful. For example, consideration could be given to reducing the role of the court, such as by empowering insolvency administrators to carry out liquidation proceedings without court approval for minor decisions that do not affect creditor rights. ${ }^{44}$ Notaries could also be empowered to determine the values and oversee collateral auctions, using standardized procedures and online tools. In addition, the number of specialized bankruptcy sections could be increased and stricter time-limits introduced to expedite reorganization.

To relieve the burden on the courts, a more extensive use of out-of-court restructuring is needed. Following best practice guidelines for restructuring could further incentivize out-ofcourt workouts by banks. These principles, sponsored by the international federation of insolvency practitioners, have influenced out-of-court restructurings in many countries (Indonesia, Korea, Malaysia, Thailand, and Iceland). In some cases, government have intervened to establish a more structured framework and address creditor coordination problems, e.g., the creditor holdout problem, such as by requiring banks to sign the workout principles and agreements to arbitrate disputes or establishing creditor coordination committees with legal standing. Countries have also used tax and regulatory incentives to incentivize borrowers and financial institutions to agree to out-of-court debt restructuring (Box 8).

The use of debt-equity swaps should be promoted. Reforms could include: (i) introducing the possibility for creditors to propose a Concordato Preventivo so that they can initiate debt equity swaps (as in U.S. Chapter 11); legal charges for directors and shareholders if they oppose to a debt-equity swap in the interest of the firm; (ii) the power for the judges to impose debt-equity swaps when the equity value is zero or negative, and (iii) to ease the out-of-court enforcement procedure for pledge over shares by excluding the shareholders' right to challenge the enforcement and providing for compensation for damages in case the equity value is positive as at the time of the enforcement.

\footnotetext{
${ }^{43}$ See IMF: Selected Issues; IMF Country Report 14/284. “Judicial Reforms for Growth,” G. Esposito, S. Lanau.

${ }^{44}$ This would exempt courts from providing parties with the reasoning of judgments and allow Appeal Courts to entirely confirm the first instance judgments.
} 


\section{Box 8. The Icelandic Crisis and the Corporate Debt Restructuring}

In October 2008, Iceland faced a banking crisis of extraordinary proportions. At the end of January 2010, corporate NPL ratios peaked at 50 percent. To clean up banks' balance sheets and restore lending, the authorities strengthened the legal framework and fostered a debt restructuring process led by the private sector.

The authorities chose a voluntary debt restructuring approach led by the private sector (Figure 16). Banks were asked to distinguish between viable firms (who could be rehabilitated) and nonviable ones (who should be liquidated). The supervisor also carried out semi-annual audits to enforce timely provisioning and set quarterly targets for restructuring of loans.

To facilitate creditor coordination, banks issued common bank guidelines. The guidelines included rules on lead creditors, new financing, stay of payments, and introduced regular independent collateral valuations and reportings to the authorities. The objective was to limit hold outs and foster creditor coordination. For viable firms, the government promoted out-of-court restructuring, following the London approach.

To support the swift exit of nonviable firms, the authorities strengthened the court framework. It undertook

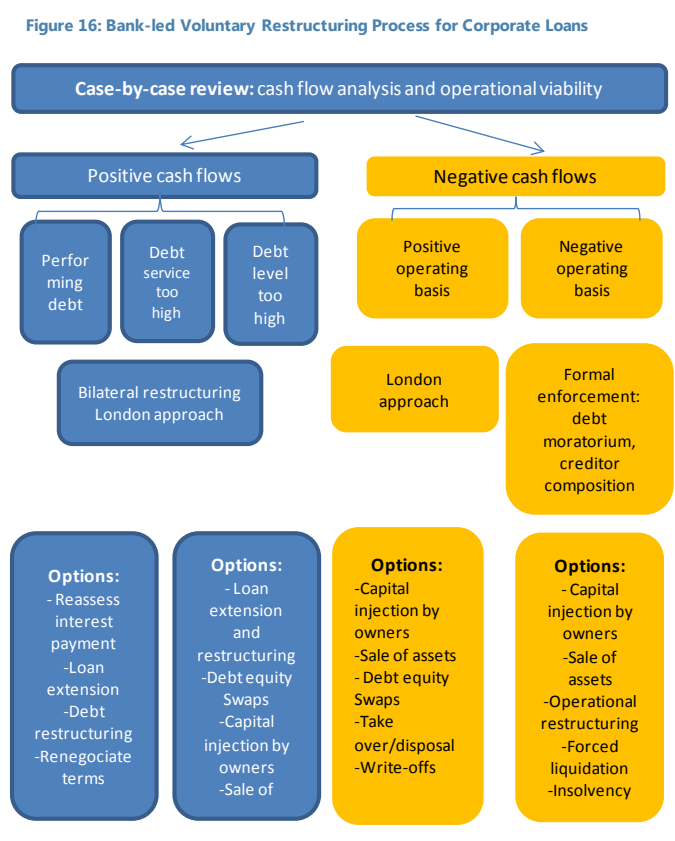

Source: IMF Iceland Article IV staff report. a comprehensive review of the corporate insolvency regime to make it a credible and efficient alternative (e.g., incorporating a liquidity test for initiation of insolvency proceedings and including secured creditors in agreed restructuring plans).

Private sector debt restructuring has made progress with a pickup in write-offs. Preliminary 2013 data showed that write-offs amounted to ISK 900 billion (50 percent of GDP) for corporates $1 /$ about three-quarters of which was for large corporations and the rest for SMEs. Over 80 percent of corporate applications had been processed by mid-2013.

Sources: Iceland 2013 Article IV Consultations and Third Post-Program Monitoring Discussions, Iceland April 2010 Staff Report for Second Review Under Stand-By Arrangement, Iceland June 2011 Fifth Review Under the Stand-By Arrangement.

$1 /$ Corporate debt accounted for 370 percent of GDP in September 2008. The debt restructuring started in 2009 on large corporate and in December 2010, for SMEs. The authorities also implemented a debt restructuring program for households, with nearly ISK 200 billion of write-offs (12 percent of GDP). Over 80 percent of corporate applications had been processed by mid-2013.

\section{Develop further NPL AMCs and corporate restructuring vehicles}

\section{NPL asset management companies (AMCs) would help support the distressed debt}

market in Italy. NPL AMCs are companies that pool and invest funds in a diversified portfolio of NPLs according to a specific objective. They are particularly effective in NPL resolution as they remove these loans from banks' balance sheets and leverage specialized skills normally not in the bank, such as in real estate servicing and corporate turnaround. AMCs can help address creditor coordination problems and strengthen loan restructuring by consolidating liabilities and allowing a single creditor to negotiate a reorganization plan with the debtor. 


\begin{abstract}
AMCs can help to close the NPL pricing gap by allowing banks to invest in AMCs and retain some of the upside returns from restructuring in a way that does not conflict with accounting rules. By repackaging bad loans in a security that can be sold to a broader range of investors, they also expand financing and more importantly, risk capital not readily available to Italian banks. From a macro and financial stability perspective, AMCs can reduce the risk of fire sales, allow for a more orderly resolution of excessive leverage (especially through equity), and to the extent they raise recovery returns, can strengthen asset prices and collateral values. By purchasing foreclosed collateral and converted equity from banks (after debt-equity swaps), AMCs can also reduce the market risk that banks face from NPL restructuring.
\end{abstract}

\begin{abstract}
AMCs have been extensively used elsewhere to facilitate NPL disposal and corporate restructuring (Sweden, Indonesia, Malaysia, Korea, and Thailand). ${ }^{45}$ These ventures were particularly effective in Asia (Box 9), where they were instrumental in bridging the NPL pricing gap as they allowed banks and private investors to share in the gains from a recovery. In terms of ownership, AMCs can be either public or private. The record on public, centralized AMCs is mixed and depended on a number of factors including their governance structure, types of assets purchased, and their value added contribution in terms of legal, tax or regulatory benefits. For both public and private AMCs, design features critical for their success include sound governance, transfer pricing at market values, adequate financing, and skill sets. ${ }^{46}$ AMCs in fact are not entirely new in Italy; a public AMC was created in 1996 to handle the bad loans of failing Banco di Napoli but met with mixed success; ${ }^{47}$ as mentioned earlier, several large banks have embarked on joint ventures with private equity funds.
\end{abstract}

\title{
Similar to $\mathrm{AMCs},{ }^{48}$ corporate restructuring vehicles (CRVs) are another instrument that go one step further and rehabilitate distressed companies. Rather than simply removing the bad assets from banks' balance sheets, CRVs look to turn around distressed companies by investing directly in the firm, restructuring their debt, and reorganizing their operations (Box 9). This could be particularly useful for Italian small and mid-sized enterprises looking to merge, expand, or shift to new lines of businesses. CRVs could allow banks to partner with outside investors, expanding the availability of financing and expertise to promote broader corporate sector restructuring.
}

\footnotetext{
${ }^{45}$ Other examples of AMC include: (i) the Resolution Trust Corporation (RTC) in the United States; (ii) the Malaysian Danaharta; (iii) the Indonesian Bank Restructuring Agency (IBRA); and more recently, (iv) the National Asset Management Agency (NAMA) in Ireland; (v) the Sociedad de Gestión de Activos procedentes de la Reestructuración Bancaria (SAREB) in Spain; and (vi) the Bank Asset Management Company (BAMC) in Slovenia.

${ }^{46}$ For a broader discussion on AMC and prerequesite for success: "Issues in the Establishment of Asset Management Companies", by Stefan Ingves, Steven A. Seelig, and Dong He.

${ }^{47}$ S.G.A. (Società per la Gestione delle Attività S.p.a.) was set up to buy (at book value), manage and recover bad loans ( $€ 6.4$ billion) from the failing Banco di Napoli (now part of ISP). Its record was mixed, as it took more than 17 years for S.G.A. to recover 83 percent of its loan, without taking into account SGA's operational expenses and inflation.

${ }^{48} \mathrm{AMC}$ may also operate as corporate restructuring vehicles if equipped with the necessary mandate and powers.
} 


\section{Box 9. Korea's Experience with Corporate Restructuring}

Korea after its financial crisis in the late 1990s undertook major bank and corporate restructuring. With NPLs reaching nearly 30 percent of GDP, banks had neither the resources nor the expertise to undertake large-scale restructuring and needed other sources of financing and tools to resolve the crisis. The Korean government played a leading role in restructuring the banking system, through changes in the legal and regulatory framework, the use of public funds, and the creation of the Korea Asset Management Company (KAMCO). While KAMCO played an important role in removing bad assets from banks' balance sheets, banks also relied heavily on private market solutions to facilitate NPL disposal.

Government-owned KAMCO has been instrumental in cleaning bank balance sheets. Starting in September 1998, KAMCO developed uniform pricing criteria and increased the average discount on its purchase prices: from $70-75$ percent of the collateral value, to 45 percent on secured loans; and from 10 to 20 percent of the principal balance to a uniform price of 3 percent on unsecured loans. This centralized approach for asset purchases provided economies of scale in disposition and collection, and freed management to focus on new loans. In the process, KAMCO has been influential in nurturing a new market for NPLs.

Private market solutions also proved to be useful to foster corporate restructuring. One initiative that proved useful was the creation of CRVs to assist banks in the market-based restructuring of viable, but distressed firms. Here corporate debt restructuring was similar to distressed debt disposal, but rather than simply removing the bad asset from bank's balance sheet, the aim was also to rehabilitate the borrower itself. The CRVs took over distressed assets from creditor banks and restructured them using an asset management company with turnaround experience, often with a foreign private partner. To encourage their use, the government provided CRVs with special regulatory treatment and tax benefits. In Korea, several types of CRVs were created:

- $\quad$ Corporate restructuring funds (CRFs): Funds which issued securities, invested in distressed firms, and received regular dividends.

- $\quad$ Corporate restructuring companies (CRCs): Restructuring companies which took majority stakes in firms, reshuffled management, restructured operations, and sold back to the market.

- $\quad$ Corporate restructuring vehicles $(C R V S)$ : SPVs set up by banks to pool distressed assets and transfer them to AMCs for specialized management with the help of outside experts.

- $\quad C$-REITs: Real estate investment trusts investing in properties from distressed firms.

The CRVs allowed banks to partner with outside investors, both domestic and overseas, to rehabilitate distressed companies. They gave banks more options to manage their NPLs and raise their recovery value. To operative effectively, they required a supportive regulatory, tax and market environment. In addition, to ensure the proper incentives for disposal and avoid the risk of hiding bad assets, it was important that the transfer of assets was done at fair market value and in a transparent manner.

This also led the government to implement important structural reforms. Insolvency laws were strengthened to expedite the exit of nonviable firms and facilitate restructuring. Time limits were introduced to expedite the reorganization process. Proceedings had to commence within one month of filing and be completed within one and a half years. Bankruptcy was automatically triggered if the process was revoked or the reorganization plan was rejected. For the most troubled and leveraged firms, the government established an out-of-court workout process. 200 banks signed a corporate restructuring agreement that committed all creditors to abide by specific workout procedures. Banks classified roughly 40 percent of SME loans as viable, and the rest as candidates for workouts.

Sources: A. Chopra et. al., "From Crisis to Recovery in Korea: Strategy, Achievements, and Lessons," IMF

WP/01/154, October 2001; Dong He, "The Role of KAMCO in Resolving Nonperforming Loans in the Republic of Korea," IMF WP/04/172, September 2004. 
Clarifying the regulatory and tax treatment of AMCs combined with possible public support could help jumpstart the NPL restructuring market. To minimize legal and regulatory uncertainty associated with AMCs, supervisors and tax authorities can clarify upfront the capital treatment of AMCs and the proper transfer pricing of bad assets. Asset transfers should take place at fair market value to avoid the warehousing of bad assets. In some cases, temporary tax relief, such as lower capital gains or transaction taxes on NPL purchases, could be considered to help launch NPL AMCs. The transfer of NPLs to these SPVs may also be subject to different types of taxes, e.g., mortgage taxes, register taxes, etc., that could be reassessed taking into account the broader macro benefits of removing quickly NPLs from bank balance sheets. ${ }^{49}$ Public funds, both from national and European institutions, such as the European Investment Bank and European Investment Fund, could also be invested as seed money to develop private AMCs, especially to address market gaps, such as for smaller banks who may lack the resources to dispose and restructure NPLs. ${ }^{50}$

Building on efforts to promote high-quality securitization (HQS), the Italian NPL-ABS market could provide another channel for offloading distressed assets. Both banks and NPL AMCs would benefit from a liquid secondary market outlet for NPL securitization. Applying the same reporting standards for HQS to NPL securitization could support the development of the high-yield, risky end of the market. For instance, collecting and disclosing more data on underlying loan-by-loan exposures for both sound and distressed loans, and allowing investors timely access to data on historical default and loss performance for a wide range of exposures and stress periods could strengthen risk pricing and attract more qualified investors. This could also support the development of a capital market union and a pan-European market for distressed assets.

\section{Conclusion}

Timely removal of problem loans will improve Italian bank balance sheets and support new lending in the recovery. Italian banks are holding a substantial amount of bad debt, most of which has been delinquent for several years. These NPLs do not generate interest revenues, yet require funding at market rates, tie up staff resources and capital. By weighing on bank valuation, they also raise the cost of funding and leave banks vulnerable to shocks.

\section{Creating a market for selling and restructuring NPLs can support a comprehensive} strategy for addressing the NPL problem. Such a market would allow for faster and more efficient resolution of distressed assets and complements restructuring efforts by banks or

\footnotetext{
${ }^{49}$ For example, exceptions are made for securitization vehicles purchasing single loans or portfolios, but not for private equity funds.

${ }^{50}$ Such operations would need also to comply with EU State aid rules. The EU Treaty contains strict limitations on State aid to avoid distorting competition. As a principle, no State aid should be granted in any form (capital, guarantees, tax benefits, etc.). In exceptional circumstances (financial crisis, for instance), State aid can be allowed by the EU Commission (DG Competition), in exchange for strict conditionality (including bail-in of junior debt since August 2013). In some Italian banks where junior debt is partly held by retail customers, State Aid could restrict options for dealing with NPLs as it would trigger bail-in outside resolution.
} 
outside servicers. A distressed debt market would have broader macro benefits by reducing the corporate debt overhang. This in turn would complement financial restructuring by improving overall bank profitability.

\section{A NPL strategy should look to remove impediments to restructuring and enhance the} incentive for banks to sell their bad assets. Steps to strengthen provisioning practices, remove the fiscal disincentives for write-offs, and improve further the insolvency framework and out-of-court workouts would provide more incentives and instruments for banks to dispose of their bad assets. Fostering the creation of corporate restructuring vehicles and NPL-AMCs could help bridge the pricing gap for NPLs and allow banks to leverage outside financing and expertise in restructuring. National efforts could also be linked and supported by pan-European initiatives to address NPLs, including through asset management companies or development of cross-border capital markets. Over time, such a market could become a regular instrument and outlet for banks to manage their NPLs, improve overall risk management, and promote corporate restructuring. 


\section{References}

Altman, E., 2013, "The Role of Distressed Debt Markets, Hedge Funds and Recent Trends in Bankruptcy on the Outcomes of Chapter 11 Reorganizations."

Banco de Espana, 2013, Financial Stability Review.

Bank of Italy, 2010, "Why Do (or Did?) Banks Securitize Their Loans? Evidence from Italy," Affinito M. and Tagliaferri E., Number 741.

Bank of Italy, 2013, Financial Stability Review - April.

Bank of Italy, 2014, Financial Stability Review - May, November.

Bank of Italy, 2013, Statistical publications, December.

Basel Committee on Banking Supervision (BCBS), 2011, "Report on Asset Securitisation Incentives," July.

Basel Committee on Banking Supervision, 2001, “The Internal Ratings-Based Approach,” Supporting Document to the New Basel Capital Accord.

Bergström, C., Englund, P., and Thorell, P., 2003, "Securum and the Way out of the Swedish Banking Crisis," Translated by Timothy Chamberlain, May.

Boccuzzi, G., 2011, "Towards A New Framework for Banking Crisis Management, The International Debate and the Italian Model," Bank of Italy Working Paper Number 71, October.

Central Bank of Ireland, 2013, "Impairment Provisioning and Disclosure Guidelines," May.

CGFS, 2011, "The impact of sovereign credit risk on bank funding conditions", July.

Chopra and others, 2001, "From Crisis to Recovery in Korea: Strategy, Achievements, and Lessons," IMF Working Paper 01/154 (Washington: International Monetary Fund).

Cortavarria, L., Dziobek, C., Kanaya, A., and Song, I., 2010, “Loan Review, Provisioning and Macroeconomic Linkages," IMF Working Paper 00/195 (Washington: International Monetary Fund).

Deutsche Bank, 2013, "Impairments Ahead of the Asset Quality Review," Chapter on Collateral, Impact of NPL disposals, September.

Deutsche Bank, 2007, "Non-performing Loans, an Established Asset Class."

De Vincenzo and G. Ricotti, 2014, "The use of tax law from a macroprudential perspective", Bank of Italy, Note of Financial Stability, Bank of Italy.

Dong, He, 2004, "The Role of KAMCO in Resolving Nonperforming Loans in the Republic of Korea,” IMF Working Paper 04/172 (Washington: International Monetary Fund). 
Englund, P., Vihriälä, V., 2003, "Financial Crisis in Developed Economies, the Cases of Sweden and Finland," March.

Ernst \& Young, 2013, "Flocking to Europe, Non-performing Loan Report.”

European Central Bank, 2014, “Aggregate Report on the Comprehensive Assessment.”

FDIC, Risk Management Manual of Examination Policies.

Fitch, 1997, "Securitization of Italian Non-Performing Loans."

Fitch, 2005, "IFRS: The Impact on Asset Quality Assessment in the Banking Sector," December.

Fratantoni, M. and Moore, M., 2013, "The US Mortgage Crisis: Are There Lessons for Policymakers?" February.

Fung, B., George, J., and Hohl, S., 2004, "Public Asset Management Companies in East Asia, A Comparative Study,” BIS Occasional Paper.

Gaston, E. and Song, IW, 2014, "Supervisory Roles in Loan Loss Provisioning in Countries Implementing IFRS,” IMF Working Paper 14/170 (Washington: International Monetary Fund).

Gebhardt, G., "Mandatory IFRS Adoption and Accounting Quality of European Banks," Journal of Business Finance and Accounting, forthcoming.

IFC, 2012, Distressed Asset Transfer Handbook: General Guidelines for the Purchase and Sale of Distressed Assets in the Financial Sector.

"Insight and foresight. Navigating the European loan portfolio market.” Linklaters, 2014.

International Monetary Fund, 2012, "Basel Core Principles for Effective Banking SupervisionDetailed Assessment of Compliance," for Brazil and Japan (Washington: International Monetary Fund).

—, 2014, “Global Financial Stability Report,” (GFSR), May (Washington: International Monetary Fund).

_ 2013, “Global Financial Stability Report,” (GFSR), October (Washington: International Monetary Fund).

, 2013, "Euro Area Policies: Article IV Consultation," Staff Country Report No. 13/231

(Washington: International Monetary Fund).

, 2013, “Iceland: Article IV Consultation,” Country Report No. 13/256 (Washington: International Monetary Fund).

, 2011, "Iceland: Staff Report for the Fifth Review Under the Stand-By Arrangement, and Request for Modification of Performance Criteria and Rephasing of Access," Country Report No. 11/125 (Washington: International Monetary Fund). 
, 2010, “Iceland: Staff Report for Second Review Under Stand-By Arrangement and Request for Extension of the Arrangement, Rephasing of Access and Establishment of Performance Criteria," Country Report No. 10/95 (Washington: International Monetary Fund).

— 2014, "Italy: Article IV Consultation," Staff Country Report and Selected Issues No. 14/284 (Washington: International Monetary Fund).

_ 2013, "Italy: Article IV Consultation," Staff Country Report and Selected Issues No. 13/298-299 (Washington: International Monetary Fund).

_ , 2013, "Italy: Financial System Stability Assessment," IMF Country Report No. 13/300 (Washington: International Monetary Fund).

_ 2013, "Italy: Detailed Assessment of Observance of Basel Core Principles for Effective Banking Supervision," (Washington: International Monetary Fund).

— 2013, "Ireland: Tenth review under the Extended Arrangement," IMF Country Report No. 13/163 (Washington: International Monetary Fund). ,2003, “Japan's Lost Decade, Policies for Economic Revival.”

Kim, T., 2003, "Corporate Restructuring in Korea and its Application to Japan: Corporate Restructuring Vehicles," Securities Research Institute.

Krahnen, J., 2008, "Multiple Lenders and Corporate Distress: Evidence on Debt Restructuring, Antje Brunner and Jan Pieter Krahnen," Review of Economic Studies.

Lanau, S., Esposito, G., and Pompe., S., 2014, "Judicial System Reform in Italy: A Key to Growth," IMF Working Paper 14/32 (Washington: International Monetary Fund).

Laryea, T., 2010, “Approaches to Corporate Debt Restructuring in the Wake of Financial Crises," (Washington: International Monetary Fund).

Linklaters LLP, 2014, "Insight and Foresight, Navigating the European Loan Portfolio Market."

Liu, Y. and Rosenberg, B., 2013, "Dealing with Private Debt Distress in the Wake of the European Financial Crisis A Review of the Economics and Legal Toolbox," IMF Working Paper 13/44 (Washington: International Monetary Fund).

Ohashi, K. and Singh, M., 2004, “Japan's Distressed Debt Market,” IMF Working Paper 04/86 (Washington: International Monetary Fund).

PricewaterhouseCoopers (PwC), 2013, “The Italian NPL Market, A New Beginning,” March.

UCG, “UniCredit Group: Guidelines of Strategic Plan 2013-18,” 2014.

Zoli E., 2013, "Italian Sovereign Spreads: Their Determinants and Pass-through to Bank Funding Costs and Lending Conditions," IMF Working Paper 13/84 (Washington: International Monetary Fund). 